\title{
Experience enhances certainty about olfactory stimuli under bulbar cholinergic control
}

\author{
Christina Cho and Christiane Linster
}

Computational Physiology Lab, Department of Neurobiology and Behavior, Cornell University, Ithaca, New York 14850, USA

\begin{abstract}
We present evidence that experience and cholinergic modulation in an early sensory network interact to improve certainty about olfactory stimuli. The data we present are in agreement with existing theoretical ideas about the functional role of acetylcholine but highlight the importance of early sensory networks in addition to cortical networks. We use a simple behavioral paradigm in mice which allows us to measure certainty about a stimulus via the response amplitude to a condition and novel stimuli. We conclude that additional learning increases certainty and that the slope of this relationship can be modulated by activation of muscarinic cholinergic receptors in the olfactory bulb.
\end{abstract}

Differentiating sensory stimuli is very important for our survival, and some animals rely primarily on the olfactory system in order to survive. Given the variability of olfactory stimuli, the presence of background stimuli as well as internal computational "noise," a degree of uncertainty as to the identity of a stimulus is always present when making decisions based on incoming stimuli (Pouget et al. 2016). The degree of certainty about a stimulus can be improved with experience, that is, if the animal is able to sample a wide distribution of instances then specific priors can be formed about a given stimulus. In addition to experience and learning, changes in internal state such as attention, stress, or metabolic needs can also affect certainty about a stimulus by redirecting and modulation computational resources. Among the most commonly discussed neuromodulatory system, acetylcholine (ACh) has been proposed to be associated with attentional processing that is important for learning and memory (Yu and Dayan 2002, 2005). In particular, Hasselmo and colleagues (Hasselmo and Bower 1993; Hasselmo 1995; Barkai and Hasselmo 1997) proposed, first in olfactory piriform cortex then in hippocampal areas, that acetylcholine could control the switch between read-in and readout in cortical attractor models. Experiments by Holland et al. (Baxter et al. 1997, 1999; Holland and Gallagher 1999) suggested that the presence of ACh could signal the degree of uncertainty of a stimulus, increasing plasticity and the opportunity to learn. We recently proposed a model of cholinergic regulation of encoding (bottom up or read-in) and recall (top down or read out) in the olfactory system in which levels of ACh are determined by the strength and quality of cortical memories (de Almeida et al. 2016). ACh then modulates sensory representations in the OB and at the same time plasticity in cortical networks (de Almeida et al. 2013, 2016, Devore et al. 2014). Cholinergic inputs to the OB have been shown to modulate stimulus representations, discrimination between stimuli, strength of learning, and short term memory (Wilson et al. 2004; Chaudhury et al. 2009; Fletcher and Chen 2010; Devore and Linster 2012; Devore et al. 2012, 2014, 2016; Bendahmane et al. 2016; Linster and Cleland 2016). We here propose a framework for integrating results on cholinergic modulation of olfactory bulb neural processing with theoretical ideas about modulation of certainty (Yu and Dayan 2005). We propose that certainty about a stimulus depends on the opportunities to experience the stimulus and its behavioral relevance about the stimulus (encoding or read-in) as on the pres-

Corresponding author: CL243@cornell.edu

Article is online at http://www.learnmem.org/cgi/doi/10.1101//m.051854.120. ence of ACh during the encoding process. In other words, both increased experience and presence of ACh can increase certainty about a stimulus and these processes can compensate for each other; these effects can happen as early as in the first sensory network, the olfactory bulb rather than in higher cognitive brain areas.

To this goal, we modified an existing olfactory behavioral paradigm to assess certainty about olfactory stimuli in mice and tested to what extent training and cholinergic modulation interact and compensate for each other in modulating the strength and specificity of an odor-reward association (Linster and Hasselmo 1999; Linster and Smith 1999; Cleland et al., 2002). Strength and specificity of an odor reward association are both direct measures for how certain an animal is about the identity of a stimulus. We measure the magnitude of the response to a conditioned odor (strength) as well as that to related novel odors (specificity) during unrewarded trials; both of these directly reflect certainty about the odor stimulus and can be manipulated by changes in stimulus concentration, previous experience, presence for background odorants, as well manipulations of olfactory bulb processing (Giannaris et al. 2002; Cleland and Narla 2003, Wiltrout et al. 2003; Cleland et al. 2009).

Eight male C57BL/6J mice served as subjects for the experimental procedure. Mice were housed in groups until surgery and individually after, had access to unlimited access to water at all times and were food restricted during behavioral testing. All experimental procedures were done under the protocol approved by the Cornell University Institutional Animal Care and Use Committee in accordance with National Institutes of Health (NIH) guidelines. The experimental apparatus used was a clear Plexiglas chamber that consisted of a resting side, a movable opaque black barrier in the middle, and a testing side in which two petri dishes (VWR, bottom) filled with white, dried play sand (Yard Right), one scented and the other unscented can be placed. To scent the odorized dish, $60 \mu \mathrm{L}$ of odor was pipetted onto $5 \mathrm{~mL}$ of sand and covered up with an additional $5 \mathrm{~mL}$ of sand. If the odor was to be rewarded, a small sucrose pellet was added to the sand. Odors are listed in Table 1. After acclimatization to the apparatus, mice were trained to retrieve a pellet from the dishes. Mice then underwent

(C) 2020 Cho and Linster This article is distributed exclusively by Cold Spring Harbor Laboratory Press for the first 12 months after the full-issue publication date (see http://learnmem.cshlp.org/site/misc/terms.xhtml). After 12 months, it is available under a Creative Commons License (AttributionNonCommercial 4.0 International), as described at http://creativecommons. org/licenses/by-nc/4.0/. 
Table 1. List of odorants and dilutions used in experiment

\begin{tabular}{|c|c|c|c|c|c|c|c|c|}
\hline & $\mathrm{C} 2$ & $\begin{array}{c}\mu \mathrm{L} \text { in } 50 \mathrm{~mL} \\
\mathrm{MO}\end{array}$ & C3 & $\begin{array}{c}\mu \mathrm{L} \text { in } 50 \mathrm{~mL} \\
\mathrm{MO}\end{array}$ & $\mathrm{C} 4$ & $\begin{array}{c}\mu \mathrm{L} \text { in } 50 \mathrm{~mL} \\
\mathrm{MO}\end{array}$ & $\mathrm{x}$ & $\begin{array}{c}\mu \mathrm{L} \text { in } 50 \mathrm{~mL} \\
\mathrm{MO}\end{array}$ \\
\hline A & Propanoic acid & 20 & Butanoic acid & 65 & $\begin{array}{l}\text { Pentanoic } \\
\text { acid }\end{array}$ & 225 & 3-Heptanone & 33 \\
\hline B & Hexyl acetate & 114 & Amyl acetate & 36 & Butyl acetate & 11 & Anisole & 26 \\
\hline C & Pentanol & 38 & Hexanol & 128 & Heptanol & 420 & Benzaylamine & 150 \\
\hline D & Hexanoic acid & 745 & $\begin{array}{l}\text { Heptanoic } \\
\text { acid }\end{array}$ & 2300 & Octanoic acid & 6900 & Neryl acetate & 8200 \\
\hline$E$ & $\begin{array}{l}\text { Butyl } \\
\text { hexanoate }\end{array}$ & 815 & Pentanoate & 290 & Butyrate & 83 & Cironellal & 830 \\
\hline $\mathrm{F}$ & Octanal & 74 & Heptanal & 36 & Hexanal & 12 & $\begin{array}{l}\text { Trans-2-hexenyl } \\
\text { acetate }\end{array}$ & 82 \\
\hline G & Ethyl butyrate & 10 & Propyl & 26 & Butyl & 280 & 2-Hexanone & 10 \\
\hline $\mathrm{H}$ & Butanal & 4 & Pentanal & 4 & Hexanal & 12 & Methyl butyrate & 4 \\
\hline 1 & $\begin{array}{l}\text { Heptyl } \\
\text { butyrate }\end{array}$ & 2300 & $\begin{array}{l}\text { Hexyl } \\
\text { butyrate }\end{array}$ & 815 & $\begin{array}{l}\text { Pentyl } \\
\text { butyrate }\end{array}$ & 290 & Isovaleric acid & 190 \\
\hline
\end{tabular}

cannulation surgery and were quickly retrained after recovery. The surgical procedure for cannulation in the olfactory bulbs followed our usual protocol (Guerin et al. 2008; Dillon et al. 2013) to insert cannula bilaterally into the OBs.

Cholinergic drugs were infused into the main OBs 20 min before behavioral testing $(0.02 \mathrm{~mL} / \mathrm{min}$ with either $2 \mathrm{~mL}$ of saline, the nonselective muscarinic antagonist scopolamine hydrobromide (22 mM, Sigma-Aldrich for each OB) or the selective nicotinic antagonist methyllycaconitine citrate hydrate (MLA; $19.0 \mathrm{mM}$; Tocris Bioscience). Dosages were chosen based on previous studies of cholinergic modulation of OB (Chaudhury et al. 2009; Devore et al. 2014). After infusion, mice were trained to associate an odorant with the reward during 4,8 , or 12 consecutive trials with $\sim 1$ min intertrial intervals. We chose a maximum of 12 trials because we know from previous experiments that 12 trials suffice to create a strong and selective odor-reward association in mice (Cleland et al. 2009). On each trial, mice were presented with a scented rewarded and an unscented nonrewarded dish and allowed to dig for the reward until they found it; the physical location of the dishes was varied among trials. Trials lasted until mice retrieved the reward with a maximum time of $1 \mathrm{~min}$ allowed; trials that exceeded the 1 min time were marked as incomplete, After the training trials, during the same session, mice were presented with two unrewarded dishes, one scented (with the conditioned odor or one of three novel odors) one unscented for 1 min trials. On a given day, mice were trained under either saline, scopolamine (muscarinic antagonist) or MLA (nicotinic antagonist), using a different odor set. Each odor set was used only once, and the order of odor sets and drug treatments were randomized and counterbalanced among mice. During test trials, the time mice spent digging in an odorized dish was recorded as dependent variable. The time spent digging in the absence of reward is a measure for the degree to which mice associate a conditioned odorant with the reward and to what degree they confuse a novel odorant with the conditioned odor (Cleland et al. 2002). To assess certainty about the stimulus identity, within odor sets comprising straight chain aliphatic odorants, repeatedly shown to represent an axis of perceptual variation (Linster and Hasselmo 1999; Cleland et al. 2002, 2009), we used one odorant known to be perceptually highly similar to the conditioned odor (one carbon removed from the conditioned odor), one less similar (two carbons removed) and one unrelated. The behavioral test allowed us to measure the effects of training and blockade of cholinergic receptors on the strength of the learned odor-reward association and on the specificity of this association, both of which directly measure how certain mice are about the stimulus presented to them. Repeated measures ANOVA using digging time during unrewarded trials as dependent variable with drug and trial number as between subjects factor and test odor as within subjects factor showed an overall significant effect of test odor $\left(F_{\text {odor }(3,49)}=31.350 ; P<0.001\right)$, significant interactions between test odor and drug $\left(F_{\text {odor }}{ }^{*}\right.$ drug $\left.(6,98)=2.852 ; P=0.014\right)$, test odor and number of trials $\left(F_{\text {odor }^{*} \text { trials }}(6,98)=2.855 ; P=0.009\right)$, and test odor, number of trials, and drug $\left(F_{\text {odor }^{*} \text { trials }}{ }^{*}\right.$ drug $(12,129.993)=$ $1.825 ; P=0.042)$. These results show that the drugs and the number of training trials both affected how much the mice dug in unrewarded test odors, and that drugs modulated the effects of training trials. Figure $1 \mathrm{~A}$ shows the average digging times of each experimental group in response to the test odors $(\mathrm{C} 2, \mathrm{C} 3, \mathrm{C} 4$, and $X)$ as a function of the number of training trials $(4,8$, or 12$)$. We found no effect of drug on overall average digging times for the conditioned odor $\left(F_{(2,69)}=2.512 ; P=0.089\right)$ indicating that drug treatments did not affect overall activity levels. 
Experience enhanced certainty about the conditioned odor in all mice as evidenced by an increase in response to the conditioned odor during test trials; blockade of muscarinic receptors significantly decreased this relationship. In saline treated mice, a significant correlation between the number of training trials and their digging times in the conditioned odor $(R=0.597 ; P=0.002)$ was measured. This correlation was lower in scopolamine treated mice $(R=0.425 ; P=0.038)$ but similar to saline treated mice in MLA treated mice $(R=0.611 ; P=0.002)$.

In addition to increasing certainty about the conditioned stimulus, experience also decreased the tendency to confuse a perceptually similar stimulus with the conditioned odor. Pairwise comparisons using Wilk's Lambda (alpha=0.05) analyzed to what degree mice in each drug group were able to discriminate between the conditioned odor and each test odor (Table 2). Saline treated mice discriminated better as training increased, with even the most similar odor (C3) discriminated after 12 trials (Fig. 1A, saline). Scopolamine treated mice discriminated only the unrelated odor $(\mathrm{X})$ after eight trials, but after 12 trials they were able to discriminate the less similar odor (C4) as well; in other words, their discrimination proceeded with the same slope but delayed by four trials (Fig. 1A, Scop). Interestingly, MLA treated mice behaved similarly to saline treated mice with the exception of C3, which they did not learn to discriminate even after 12 training trials (Fig. 1A, MLA).

To further analyze to what degree the number of training trials affected odor discrimination, we used a measure called discrimination index (DI), which is calculated as the difference between two odor responses divided by their sum. This index tends toward 1 when response to the novel odor is much smaller than to the conditioned odor and toward -1 when the response to the novel odor is much bigger than that the conditioned odor. We found that for saline treated mice, discrimination between the conditioned odor (C2) and C3 $(R=0.451, P=0.035)$, and C2 and C4 $(R=$ $0.743, P=0.001$ ) were highly correlated with the number of training trials (Fig. 2A). In contrast, there was no significant correlation between the amount of training and discrimination of X $(R=0.267, P=0.284)$ because this odor was always well discriminated. Scopolamine treated mice showed strong correlations between the number of training trials and the discrimination of all three test odors $(R=0.458 ; P=0.028, R=0.525 ; P=0.01$ and $R=0.445 ; P=0.033$ ), which shows that these mice had to learn to discriminate $\mathrm{X}$ as well and generally increased their discrimination ability (or the specificity of the association) as training increased (Fig. 2B). Interestingly, MLA treated mice showed a significant cor-

Table 2. Summary showing to what degree mice in each drug group discriminated between the conditioned odor (C2) and test odors $(C 3, C 4, X)$

\begin{tabular}{lccc}
\hline & \multicolumn{3}{c}{ Saline } \\
\cline { 2 - 4 } \#trials & $\mathbf{4}$ & $\mathbf{8}$ & $\mathbf{1 2}$ \\
\hline Saline & & & $*$ \\
C3 & & $*$ & $*$ \\
X & $*$ & $*$ & \\
Scop & & & $*$ \\
C3 & & $*$ & \\
C4 & & & \\
X & & $*$ \\
MLA & & $*$ & $*$ \\
C3 4 & $*$ & $*$ & \\
X & & & \\
\hline
\end{tabular}

* Indicates significant discrimination between the test odor and C2.

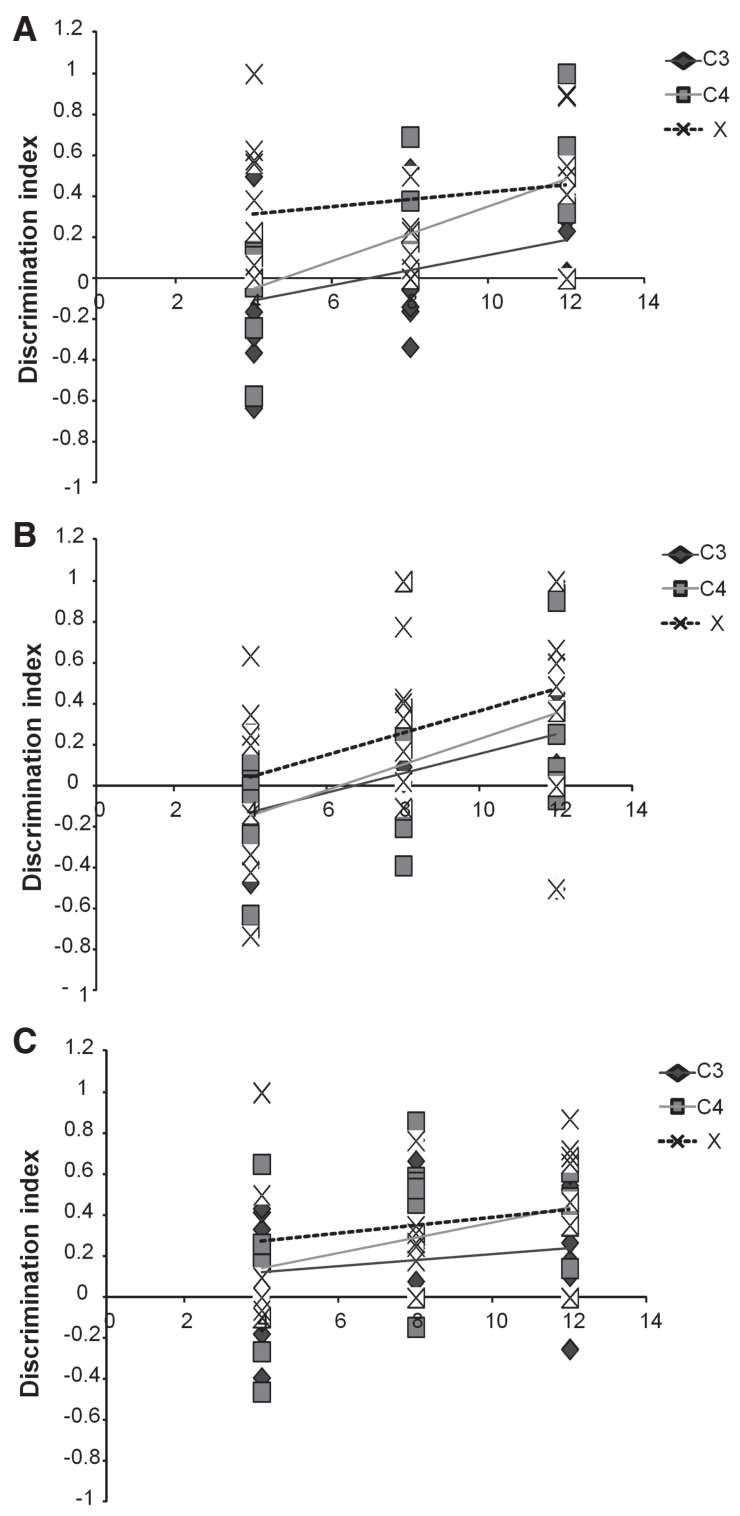

Figure 2. Degree of discrimination between novel and conditioned odors. (A) Discrimination index for $\mathrm{C} 3, \mathrm{C} 4$, and $\mathrm{X}$ as a function of number of training trials for saline treated mice. $(B)$ Discrimination index for $\mathrm{C} 3, \mathrm{C} 4$, and $\mathrm{X}$ as a function of number of training trials for scopolamine treated mice. (C) Discrimination index for C3, C4, and X as a function of number of training trials for MLA treated mice.

relation between the number of training trials and discrimination of C4 $(R=0.498 ; P=0.018)$, but not of C3 or X $(R=-0.393$; $P=0.094$ and $R=0.026 ; P=0.914$ ) (Fig. $2 \mathrm{~B}$ ); these mice could always discriminate $\mathrm{X}$, but never $\mathrm{C} 3$ hence responses to these odors were not correlated with amount of training (Fig. 2C). Thus, this suggests that MLA impairs discrimination of C3 independently of learning by affecting odor representations, as suggested by our previous experiments in rats (Devore et al. 2014). Our computational models and electrophysiology suggested that odor representations can be modulated by nicotinic receptor activation as early as the $\mathrm{OB}$ glomerular layer, creating highly overlapping odor representations for C2 and C3 (Cleland et al. 2002) which cannot be disambiguated by more learning in postsynaptic targets (Chaudhury et al. 2009; de Almeida et al. 2013; Li and Cleland 2013). Activation of muscarinic receptors changes the dynamics 
of odor representations rather than the overlap per se and would modulate plasticity and read out in cortical areas (de Almeida et al. 2013; Devore et al. 2014).

Our results show that experience enhances certainty about odor stimuli under cholinergic regulation as early as in the olfactory bulb. We manipulated cholinergic modulation in a primary sensory network only and not in cortical networks. Specifically, our results show that saline-infused mice have stronger recall of the conditioned odor and are better able to discriminate chemically similar odors as the number of conditioning trials increases, while scopolamine or MLA- infused mice showed impaired performance as a function of training trials. Scopolamine-infused mice were able to compensate for lack of muscarinic receptor activation through more experience, whereas MLA-infused mice behaved similarly to saline-infused mice with the exception of never learning to discriminate the most similar odor even after a great number of training trials. Based on our previous work (de Almeida et al. 2013; Li and Cleland 2013; Li et al. 2015), we propose that certainty about olfactory stimuli is increased when ACh in the OB enhances dynamics and synchrony via activation of muscarinic receptors: activation of muscarinic receptors enhances certainty and decreases signal-to-noise ratio (Devore and Linster 2012; de Almeida et al. 2013; Devore et al. 2014). We do not differentiate effects during acquisition and recall in these experiments but rather look at how the blockade of cholinergic receptors effects the expression and evolution of certainty in our paradigm in a continuous manner. Previous experiments have shown no effect of cholinergic receptor blockade on well-learned odor-reward associations (Devore et al. 2014); in the experiments presented here there is a limited amount of training (12 trials maximal) which does not lead to overtraining. Our experiments differ from other groups' in that we manipulate acetylcholine in a primary sensory area rather than in a cortical network. We show that modulation of sensory representations can enhance certainty. We propose that a functional loop between sensory, cortical, and cholinergic networks to modulate encoding and recall as needed.

\section{Acknowledgments}

The authors thank Matthew Einhorn for technical support and Pankush Kumar and Angelina Shi for assistance with experiments. This work was support by CRCNS: NSF 1724221 to C.L.

\section{References}

Barkai E, Hasselmo MH. 1997. Acetylcholine and associative memory in the piriform cortex. Mol Neurobiol 15: 17-29. doi:10.1007/BF02740613

Baxter MG, Holland PC, Gallagher M. 1997. Disruption of decrements in conditioned stimulus processing by selective removal of hippocampal cholinergic input. J Neurosci 17: 5230-5236. doi:10.1523/JNEUROSCI .17-13-05230.1997

Baxter MG, Bucci DJ, Holland PC, Gallagher M. 1999. Impairments in conditioned stimulus processing and conditioned responding after combined selective removal of hippocampal and neocortical cholinergic input. Behav Neurosci 113: 486-495. doi:10.1037/0735-7044.113.3.486

Bendahmane M, Ogg MC, Ennis M, Fletcher ML. 2016. Increased olfactory bulb acetylcholine bi-directionally modulates glomerular odor sensitivity. Sci Rep 6: 25808. doi:10.1038/srep25808

Chaudhury D, Escanilla O, Linster C. 2009. Bulbar acetylcholine enhances neural and perceptual odor discrimination. J Neurosci 29: 52-60. doi:10 .1523/JNEUROSCI.4036-08.2009

Cleland TA, Narla VA. 2003. Intensity of olfactory acuity. Behav Neurosci 117: $1434-1440$.

Cleland TA, Morse A, Yue EL, Linster C. 2002. Behavioral models of odor similarity. Behav Neurosci 116: 222-231. doi:10.1037/0735-7044 .116 .2 .222
Cleland TA, Narla VA, Boudadi K. 2009. Multiple learning parameters differentially regulate olfactory generalization. Behav Neurosci 123: 26-35. doi:10.1037/a0013991

de Almeida L, Idiart M, Linster C. 2013. A model of cholinergic modulation in olfactory bulb and piriform cortex. J Neurophysiol 109: 1360-1377. doi:10.1152/jn.00577.2012

de Almeida L, Idiart M, Dean O, Devore S, Smith DM, Linster C. 2016. Internal cholinergic regulation of learning and recall in a model of olfactory processing. Front Cell Neurosci 10: 256. doi:10.3389/fncel.2016 .00256

Devore S, Linster C. 2012. Noradrenergic and cholinergic modulation of olfactory bulb sensory processing. Front Behav Neurosci 6: 52 . doi:10 $.3389 /$ fnbeh.2012.00052

Devore S, Manella LC, Linster C. 2012. Blocking muscarinic receptors in the olfactory bulb impairs performance on an olfactory short-term memory task. Front Behav Neurosci 6: 59. doi:10.3389/fnbeh.2012.00059

Devore S, de Almeida L, Linster C. 2014. Distinct roles of bulbar muscarinic and nicotinic receptors in olfactory discrimination learning. J Neurosci 34: 11244-11260. doi:10.1523/JNEUROSCI.1499-14.2014

Devore S, Pender-Morris N, Dean O, Smith D, Linster C. 2016. Basal forebrain dynamics during nonassociative and associative olfactory learning. J Neurophysiol 115: 423-433. doi:10.1152/jn.00572.2015

Dillon TS, Fox LC, Han C, Linster C. 2013. 17ß-estradiol enhances memory duration in the main olfactory bulb in CD-1 mice. Behav Neurosci 127: 923-931. doi:10.1037/a0034839

Fletcher ML, Chen WR. 2010. Neural correlates of olfactory learning: critical role of centrifugal neuromodulation. Learn Mem 17: 561-570. doi:10 $.1101 / \operatorname{lm} .941510$

Giannaris EL, Cleland TA, Linster C. 2002. Intramodal blocking between olfactory stimuli in rats. Physiol Behav 15: 717-722.

Guerin D, Peace ST, Didier A, Linster C, Cleland TA. 2008. Noradrenergic neuromodulation in the olfactory bulb modulates odor habituation and spontaneous discrimination. Behav Neurosci 122: 816-826. doi:10.1037/ a0012522

Hasselmo ME. 1995. Neuromodulation and cortical function: modeling the physiological basis of behavior. Behav Brain Res 67: 1-27. doi:10.1016/ 0166-4328(94)00113-T

Hasselmo ME, Bower JM. 1993. Acetylcholine and memory. Trends Neurosci 16: 218-222. doi:10.1016/0166-2236(93)90159-J

Holland PC, Gallagher M. 1999. Amygdala circuitry in attentional and representational processes. Trends Cogn Sci 3: 65-73. doi:10.1016/ S1364-6613(98)01271-6

Li G, Cleland TA. 2013. A two-layer biophysical model of cholinergic neuromodulation in olfactory bulb. J Neurosci 33: 3037-3058. doi:10 $.1523 /$ JNEUROSCI.2831-12.2013

Li G, Linster C, Cleland TA. 2015. Functional differentiation of cholinergic and noradrenergic modulation in a biophysical model of olfactory bulb granule cells. J Neurophysiol 114: 3177-3200. doi:10.1152/jn.00324 .2015

Linster C, Cleland TA. 2016. Neuromodulation of olfactory transformations. Curr Opin Neurobiol 40: 170-177. doi:10.1016/j.conb.2016.07.006

Linster C, Hasselmo ME. 1999. Behavioral responses to aliphatic aldehydes can be predicted from known electrophysiological responses of mitral cells in the olfactory bulb. Physiol Behav 66: 497-502. doi:10.1016/ S0031-9384(98)00324-2

Linster C, Smith BH. 1999. Generalization between binary odor mixtures and their components in the rat. Physiol Behav 66: 701-707. doi:10 .1016/S0031-9384(99)00007-4

Pouget A, Drugowitsch J, Kepecs A. 2016. Confidence and certainty: distinct probabilistic quantities for different goals. Nat Neurosci 19: 366-374. doi:10.1038/nn.4240

Wilson DA, Fletcher ML, Sullivan RM. 2004. Acetylcholine and olfactory perceptual learning. Learn Mem 11: 28-34. doi:10.1101/lm.66404

Wiltrout C, Dogra S, Linster C. 2003. Configurational and nonconfigurational interactions between odorants in binary mixtures. Behav Neurosci 117: 236-245.

Yu AJ, Dayan P. 2002. Acetylcholine in cortical inference. Neural Netw 15: 719-730. doi:10.1016/S0893-6080(02)00058-8

Yu AJ, Dayan P. 2005. Uncertainty, neuromodulation, and attention. Neuron 46: 681-692. doi:10.1016/j.neuron.2005.04.026

Received April 23, 2020; accepted in revised form June 26, 2020. 


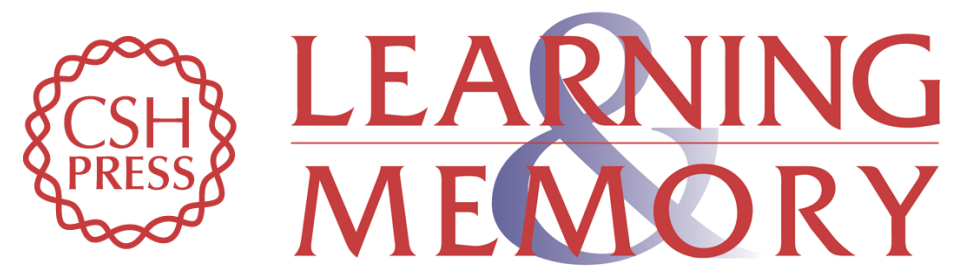

\section{Experience enhances certainty about olfactory stimuli under bulbar cholinergic control}

Christina Cho and Christiane Linster

Learn. Mem. 2020, 27:

Access the most recent version at doi:10.1101/lm.051854.120

References This article cites 31 articles, 6 of which can be accessed free at:

http://learnmem.cshlp.org/content/27/10/414.full.html\#ref-list-1

Creative This article is distributed exclusively by Cold Spring Harbor Laboratory Press for the

Commons

first 12 months after the full-issue publication date (see

License http://learnmem.cshlp.org/site/misc/terms.xhtml). After 12 months, it is available under a Creative Commons License (Attribution-NonCommercial 4.0 International), as described at http://creativecommons.org/licenses/by-nc/4.0/.

Email Alerting Receive free email alerts when new articles cite this article - sign up in the box at the Service top right corner of the article or click here. 